\title{
DIGITAL IMAGE CORRELATION METHOD FOR ANALYSIS OF REINFORCED CONCRETE STRUCTURES
}

\author{
${ }^{1}$ Blikharskyy Ya.Z., PhD, Associate Professor, \\ Yaroslav.Z.Blikharskyy@lpnu.ua, ORCID: 0000-0002-3374-9195 \\ ${ }^{1}$ Kopiika N.S., student, \\ kopijka.nadija.1999@gmail.com, ORCID: 0000-0003-2270-4028 \\ ${ }^{1}$ Lviv Polytechnic National University \\ 12 st. S. Bandera, Lviv, 79013, Ukraine
}

\begin{abstract}
Reinforced concrete structures are widely used nowadays.in different fields of applications due to the number of its remarkable properties. The optimal technique for its mechanical characteristics`estimation is an important theoretical and practical issue. Recently there is the common practice to use the Digital Image Correlation method for reinforced concrete structures analysis. The main purpose of this work is to carry out the thorough theoretical research of DIC method, to identify its advantages and disadvantages. The detailed review of existing theoretical scientific investigations and experimental works is presented in the paper. Main prerequisites of this method application are investigated and perspectives of its further development are outlined. The conclusion that the DIC method is strongly recommended for further usage and development because of its high accuracy and simplicity of experimental application was made.
\end{abstract}

Keywords: Digital Image Correlation, reinforced concrete structures, modeling, accuracy, material properties, experimental testing.

Introduction. Reinforced concrete structures are the most used currently on both Ukrainian and international construction market [1-3]. Moreover, reinforced concrete is one of the most common construction material for agricultural, industrial and hydro technical structures [4], which high popularity could be explained by the number of advantages, including the following [5]:

- high durability, as protected steel does not change its properties during exploitation and the concrete strength even increases over time;

- illimitable amount of structural and architectural forms which could be created;

- comparatively low maintenance, operation and care costs as well as low level of capital expenditures, due to local materials use;

- rather good resistance to atmospheric, fire, seismic and dynamic loading.

Above listed properties of this artificial material are possible to achieve because of synergic composite character of reinforced concrete as the construction material. Thus, as in reinforced concrete elements concrete works for compression when reinforcement is intended for the perception of tensile forces, the material itself should be considered as the complex system of complimentary components [6]. Obviously, both its mechanical properties as well as its behaviour under the load are much more complicated than those for classical natural materials.

Therefore, the optimal technique for its mechanical characteristics estimation is an important theoretical and practical issue $[7,8]$.

The analysis of experimental data for RC elements usually requires thorough measuring of stress-strain parameters. As was affirmed in works of Chu T.et al., 1985 [9] and B. Pan et al., 2009 [10] one of the most appropriate techniques is the method of Digital Image Correlation (DIC). This method has already become one of the most commonly used in various fields of application including infrastructural, agricultural and industrial constructions, material science etc.

Problem formulation. Considering the fact of increasing demand in reliable approach to reinforced concrete elements testing, in this article the Digital Image Correlation Method is investigated, as this method is currently prevailing in construction scientific research and practical experiments.

Bulletin of Odessa State Academy of Civil Engineering and Architecture, 2020, no. 78, page 27-33 
Aim of work. The main purpose of this work is to carry out the thorough theoretical research and literature review of DIC method. Objectives of the study also include identification of its advantages and disadvantages, major application prerequisites and further development perspectives.

Analysis of scientific research. Digital Image Correlation Method (DIC) is commonly used in studies of building structures stress-state as one of the non-interferometric methods [11]. It has been widely discussed in the number of scientific papers [11-16] as one of the most appropriate techniques for combining the theoretical approach with controlled accuracy parameters and experimental data for in-depth analysis of the structure. Thus, the reliable model of the construction element behaviour could be obtained for further numerical computations or practical usage.

In general, DIC method could be characterised as an optical measurement with digital image processing and numerical calculations $[9,10,12]$. Its wide availability could be accounted for both great amount of special software as VIC-2D (Correlated Solutions Company, [13] and ARAMIS (GOM Company), as well as simplicity of its usage; it requires only the digital camera with high quality digital matrix and special pattern of chaotically placed black dots on the investigated surface. An example of the principal scheme of DIC method for cylindrical specimen, tested for tension is given on the Fig. 1 (Photo by Institute of materials and mechanics of Machines Slovak Academy of Sciences, [14].

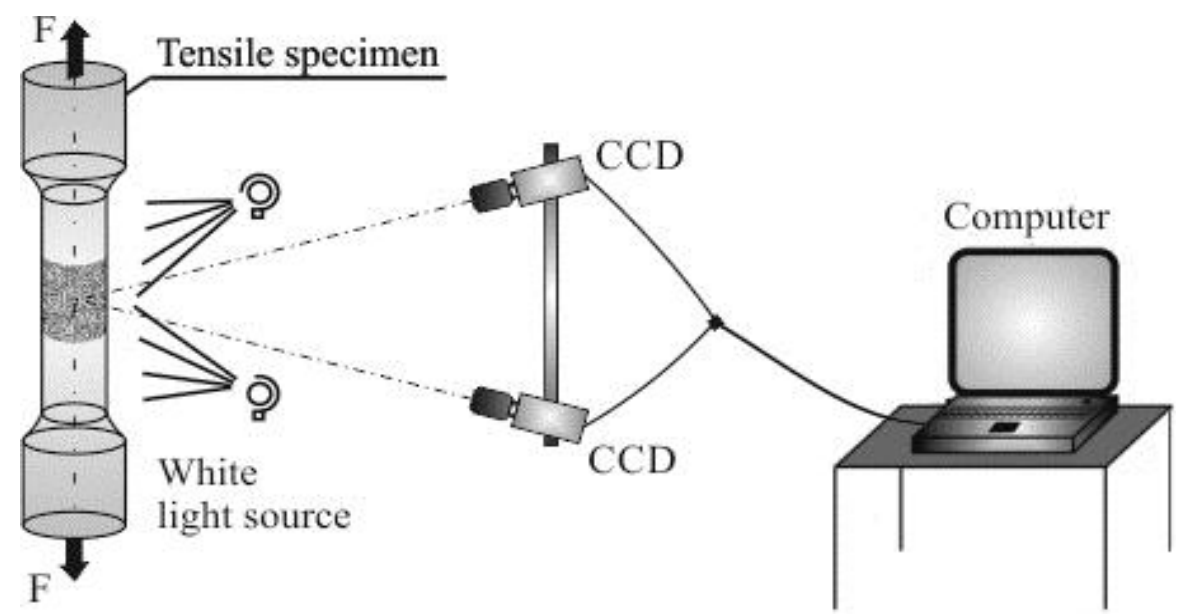

Fig. 1. Cylindrical specimen, tested for tension with the use of 3D digital image correlation method (Photo by Inst. of materials and mechanics of Machines Slovak Academy of Sciences, [14]

As was stated by Schreier H. W., 2003 [15] the method is based on comparison of relative displacements of surface points taken in a specific step and allows to define both relative deformations components $\varepsilon_{x x}$ and $\varepsilon_{y y}$ to produce the complete field of displacements and deformations in the measurement area. The principal scheme of strain field formation is demonstrated on the Fig. 2 [16].

As was confirmed by Kovalchyk, 2012 [17] the DIC method has performed itself to be significantly reliable with simultaneous simplicity of its experimental implementation.

In addition, the 3D DIC method on the binocular stereoscopy basis should be noted as the appropriate one for 3D and curved surfaces, when the 2D DIC, in contradiction, only allows to measure deformations on a plane and a rounded surface [18, 19].

Methodology and analysis of application DIC. The high accuracy of results, which could be obtained with this method and the possibility of multi-parameter modeling and analysis of the RC element behavior under the load was confirmed in the number of experimental probations both in Ukraine and abroad [5, 20-27].

For example, such technique enabled authors in [20] to produce rather convincing strain-state diagrams, taking into account the wide range of parameters. The multi-parameter type of experiment was also conducted by A. Santos et.al, 2015 [21], where with application of Digital Image Correlation an experimental evaluation of the size effect in concrete elements was performed. 
The heterogeneous character of strain changes was observed by Saldaña H. A. et. al., 2015 [22] with the use of Digital Image Correlation Method for axially loaded concrete elements. The experimental approbation of DIC was also performed for crack formation evaluating in the study of Koval M.P. and Molkov Yu. V., 2018 [5] and in comparison with classical technique its high preciseness was admitted. Similar work of Fayyad T. M. and Lees J. M, 2014 [23] presented the results of experimental investigation of small-scale reinforced concrete specimens in three-point bending, where the DIC method provided the circumstantial visualization and quantification of the reinforced concrete fracture properties.

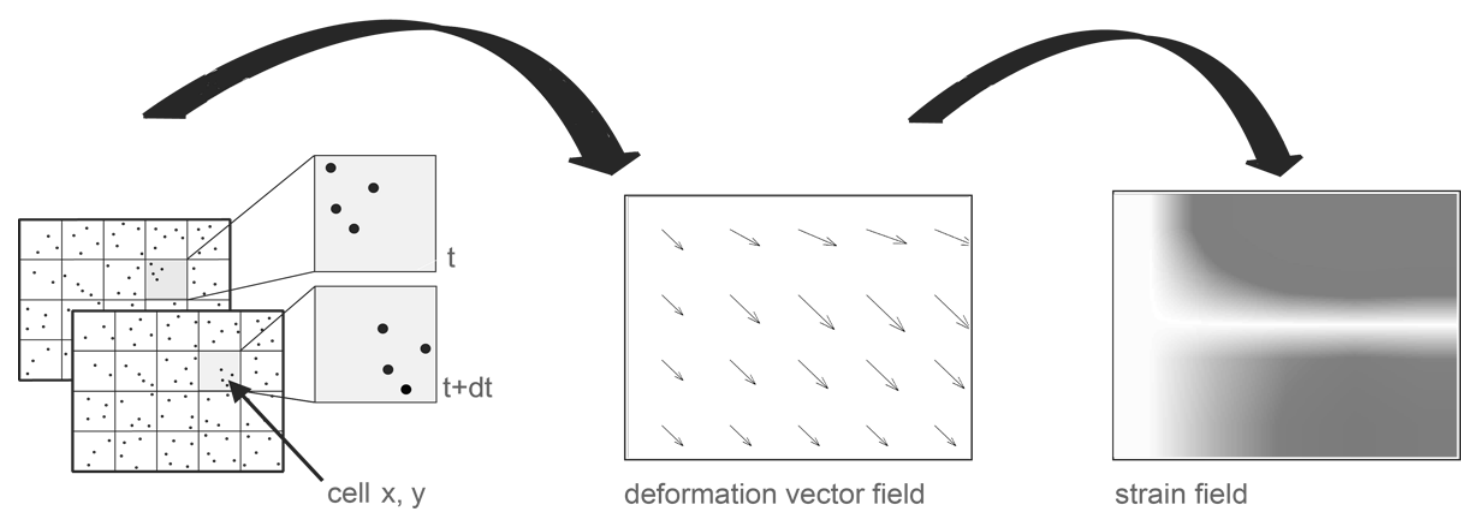

Fig. 2. The principal scheme of strain field determination with the use of DIC method (Photo by LaVision [16]

Except the bended elements with rectangular cross-sections (namely, reinforced concrete beams), possible applications for such optical method could be the RC elements, subjected to compression, as well as structures with more complex stress-strain state. For instance, in further research of Koval P.M. et. al. [18] this optical method was also approbated during the concrete cubes experimental testing.

Another example of such application could be experimental tests presented in Phd thesis of Davydenko O.O, 2016 [24]; in the paper author showed that the correlation method is an optimal approach for investigation of stress-strain state and bearing capacity of circle cross-section RC elements subjected to transverse load.

The paper of Junhwa Lee et.al, 2019 [25] proposes a static stress estimation method for concrete structures by solving an optimization problem through DIC method. Reliability of obtained results was experimentally validated and proposed method efficacy was demonstrated.

High accuracy and versatility of the method enables also to use it for more complex structural composites such as RC beams reinforced with composite materials, as was shown in the number of works [26, 27].

Although there is the number of obvious advantages of Digital Image Correlation Method, there are still certain issues, which need to be considered when choosing such approach for experimental investigation. Thus, a number of scientists of recent years have conducted studies tended to development of DIC method with the purpose of increasing its accuracy [28-30]. For example, the study of Forsey A. and Gungor S., 2016 [28] was aimed to identify the most appropriate technique for images converting. It was shown that the bicubic spline based in-house demosaicing method outperformed the other methods in terms of accuracy and aliasing suppression. Sjödahl M., 2019 in his work [29] makes an attempt to improve the method by investigation the new complex correlation function as combination of the pure intensity correlation function, the gradient correlation function and the Hessian correlation function and managed to reduce the random error by half. According to Tomicevic Z. et. al., 2013 [30] uncertainty levels during the correlation process could be reduced by introducing a mechanically-based regularization, providing the so called "educated guess" for the displacement. As a result, significant simplification and error reduction could be obtained.

Another important tendency in scientific community is towards more practical implementation of DIC method for its further usage outside the laboratory [31, 32]. For this purpose, it is necessary to

Bulletin of Odessa State Academy of Civil Engineering and Architecture, 2020, no. 78, page 27-33 
reduce the influence of various external real-conditions factors on the experiment. For elimination of external negative impacts, such as noise, lighting conditions, pattern alteration, sample shape changes, etc. software search in expanding concentric rings from the initial position along with the Newton's approximation method could be used. [31]. The separate attention should also be given to the case, when the local buckling occurs. As Hild F. and Roux S., 2012 stated in [19], the correlation residuals can be used to detect it and a more detailed analysis is needed. Remarkable work has been conducted recent years in National Physical Laboratory (Teddington, United Kingdom), where the refinement of the technique has been developed, aiming to enable its use for in-situ measurements, outside the laboratory. Another course includes enabling DIC to be used over a period of time without permanent set up usage as well as its application in hard to reach areas [32].

Results and perspectives for further research. The detailed review of existing theoretical scientific investigations and experimental works is presented in the article. On the basis of conducted research and thorough analysis it could be affirmed that the method makes it possible to identify parameters of fracture and material models for reinforced concrete elements and also to validate numerical simulations. DIC method enables to bridge the gap between experimental and theoretical modelling of the RC structures` stress-strain state. With its use more complex and more representative tests might be performed to identify material parameters.

It is important also to admit that Digital Image Correlation method in many cases is the unique possible approach to measure 2D- and 3D-displacements of object surfaces and even in the bulk due to small sizes of resolutions measured and reasonable simplicity of its usage in practical situations. In the number of works, except the experimental investigations with the DIC method, also the approach is made to implement such technique to real conditions outside the laboratory. It could be strongly recommended to further develop this field of research with subsequent increase in accuracy of results and reducing possible external impacts on obtained data.

In regard to future perspectives, it could be assumed, that development of new and more powerful imaging systems and improving the principle experimental scheme will cause the increase of interest to DIC method and new fields of application formation.

Conclusions. Digital Imaging Correlation (DIC) is a technique which could ideally suit to the study of crack formation, development and material deformation and other RC elements parameters in real-world applications, as it has performed itself as reliable, accurate and comparatively low cost method.

\section{References}

[1] C. Christodoulou, I. Goodier, "Corrosion management of reinforced concrete structures", Loughborough University's Institutional Repository - Concrete (London), pp.37-39, 2014.

[2] T. Bobalo, Y. Blikharskyy, N. Kopiika, M. Volynets, "Serviceability of RC Beams Reinforced with High Strength Rebar's and Steel Plate", Lecture Notes in Civil Engineering, vol. 47, pp. 25-33, 2019.

[3] T. Bobalo, Y. Blikharskyy, N. Kopiika, M. Volynets, "Theoretical analysis of RC beams reinforced with high strength rebar's and steel plate", IOP Conf. Series: Materials Science and Engineering, vol. 708, pp. 012-045, 2019.

[4] A.P. Borysyuk, "Napruzheno-deformovanyj stan zalizobetonnyh balok pidsylenyh pid navantazhennjam stalefibrobetonom i kompozytamy pry diji malocyklovyh navantazhen", Resurso-ekonomni materialy, konstrukcii, budivli ta technologii. Zbirnyk naukovych prac, Issue 33, pp. 303-313, 2016.

[5] M.P. Koval, Y.V. Molkov, "Zastosuvannja optyko-cyfrovyh metodivdlja vyznachennja shyryny rozkryttja trischyn u zalizobetonnyh konstrukcijah", Stalezalizobetonni konstrukcii: doslidgennia, proektuvannia, budivnytstvo,ekspluatacia. Zbirnyk naukovych prac, Issue 12, pp.141-155, 2018.

[6] Y. Blikharskyy, N. Kopiika, "Doslidzhennja metodyk monitoryngu i modeljuvannja korozijnyh procesiv v zalizobetonnyh elementah", Visnyk Odeskoi dergavnoi Akademii Budivnytstva i Architektuty, vol. 77, pp. 29-37, 2019.

Bulletin of Odessa State Academy of Civil Engineering and Architecture, 2020, no. 78, page 27-33 
[7] P.V. Yasnii, O.P. Kononchuk, O. M. Yakubyshyn, V. K. Zelenskyi, "Suchasni metody diahnostyky stanu budivelnykh konstruktsii pislia yikh tryvaloi ekspluatatsii", Praci 5 Mignarodnoi naukovo-technichnoi konferencii "Poshkodgennia materialiv pid chas expluatacii, metodi yogo diagnostuvannia i prognosuvannia“", 2017, pp. 222-225.

[8] Y. Blikharskyy, N. Kopiika, "Doslidzhennja poshkodzhenyh zalizobetonnyh elementiv, osnovni metody jih vidnovlennja i pidsylennja", Resurso-ekonomni materialy, konstrukcii, budivli ta technologii. Zbirnyk naukovych prac, Issue 37, pp. 316-322, 2019.

[9] T. Chu, W. Ranson, M. Sutton, "Applications of digital-image-correlation techniques to experimental mechanics", Experimental Mechanics, vol. 25, Issue 3, pp. 232-244, 1985.

[10] B. Pan, K.M. Qian, H.M. Xie, A. Asundi, "Two-dimensional digital image correlation for in-plane displacement and strain measurement review", Measurement Science \&Technology, vol. 20, Issue 6, pp. 2001-2007, 2009.

[11] E. Zappa, N. Hasheminejad, "Digital Image Correlation Technique in Dynamic Applications on Deformable Targets", Experimental Techniques, vol. 41, Issue 4, pp. 1-11, 2017.

[12] M.A. Sutton, M. Cheng, W.H. Peters, Y.J. Chao, S.R McNeill, "Application of an optimized digital correlation method to planar deformation analysis", Image and Vision Computing, vol. 4, Issue 3, pp. 143-150, 1986.

[13] VIC-2D. Refrence Manual. Correlated Solutions. Available: http://www. correlatedsolutions.com/installs/Vic-2D-2009-Manual.pdf. Accessed on: February 06, 2020.

[14] Ústav materialov a mechaniky strojov, Slovenska Akademia. Available: http://www.umms.sav.sk/6606-sk/deformation-behaviour-of-materials-studied-by-digitalimage-correlation-method. Accessed on: February 05, 2020.

[15] H.W. Schreier, "Investigation of two and three-dimensional image correlation techniques with applications in experimental mechanics", University of South Carolina, 2003.

[16] LaVision. Available: https://www.lavision.de/en/techniques/dic-dvc. Accessed on: February 05, 2020.

[17] Ya.I Kovalchyk, "Perspektyvy vykorystannya metodu cyfrovoyikorelatsii zobragen dlya doslidgennia budivelnych construkcii", Zbirnyk naukovych prac Poltavskogo nacionlnogo technichnogo universytetu im. Yu. Kondratyuka. Serie: Galuzeve mashynobuduvannya, budivnytstvo, Issue 5, pp. 92-100, 2012.

[18] P.M. Koval, Ya.L. Ivanytsky, Ya.I. Kovalchyk, Yu.V. Molkov, Doslidgnna naprugenodeformovanogo stanu betonnych zrazkiv metodom cyfrovoi corelatsii zobragen. Available: http://publications.ntu.edu.ua/avtodorogi_i_stroitelstvo/avtodorogi_i_stroitelstvo_89/185192.pdf. Accessed on: February 07, 2020.

[19] F. Hild, S. Roux, "Digital Image Correlation", Optical Methods for Solid Mechanics. A Full-Field Approach-eds. P. Rastogi and E. Hack, eds. Wiley-VCH, Weinheim, Germany, pp. 183-228, 2012.

[20] K. Zhang, Yu.V. Molkov, Yu.M. Sobko, Ya Z. Blikharskyy, R.Ye. Chmil, "Vyznachennia mechanichnych charakterystyk I pytomoi energii ruynuvannia termozmicnennoi armatury", Physyko-chimichna mechanika materialiv. Physicochemical Mechanics of Materials, Issue 6, pp. 50-54, 2014.

[21] A.H.A Santos, R.L. Pitangueira, G.O. Ribeiro, R.B Caldas, "Study of size effect using digital image correlation", IBRACON Structures and Materials Journal, vol. 8, Issue 3, pp. 323-340, 2015. doi:10.1590/S1983-41952015000300005

[22] H.A. Saldaña, P.A. Márquez Aguilar, O.A. Molina, "Concrete Stress-Strain Characterization by Digital Image Correlation", Journal of Applied Mechanical Engineering, vol. 4:189, Issue 6, pp.1-5, 2015.

[23] T.M. Fayyad, J.M. Lees, "Application of Digital Image Correlation to reinforced concrete fracture", Procedia Materials Science, 3, pp. 1585-1590, 2014.

[24] A.A. Davydenko, "Napruzheno-deformovanyj stan ta nesucha zdatnist' zalizobetonnyh elementiv krugovogo pererizu pry diji poperechnoji syly", dis. k-ta tekhn. nauk: 05.23.01, Derzhavne pidpryjemstvo «Derzhavnyj naukovo-doslidnyj instytut budivel'nyh konstrukcij», 2016. Available: http://www.niisk.com/kom-s-ya-po-nauts- and/\%D0\%90\%D0\% B2\%D1\%82\%D0\%BE\%D1\%80\%D0\%B5\%D1\%84\%D0\%B5\%D1\%80\%D0\%B0\%D1\%82 
.pdf. Accessed on: February 07, 2020.

[25] Junhwa Lee, Eun Jin Kim, Seongwoo Gwon, Soojin Cho, Sung-Han Sim, "Uniaxial Static Stress Estimation for Concrete Structures Using Digital Image Correlation", Sensors, vol. 19, Issue 319, pp. 1-10, 2019.

[26] M. Tekieli, S.De Santis, G.de Felice, A. Kwiecien', F. Roscini, "Application of Digital Image Correlation to composite reinforcements testing", Composite Structures, vol. 160, pp. 670-688, 2017.

[27] O.V. Panchenko, "Napruzheno-deformovanyj stan zalizobetonnyh balok, pidsylenyh kompozytnymy materialamy, za energetychnym pidhodom", dis. k-ta tekhn. nauk: 05.23.01 Kyjivs'kyj nacional'nyj universytet budivnyctva i arhitektury, 2018. Available: http://www.knuba.edu.ua/ukr/wp-content/uploads/2015/09/Avtoreferat-Panchenko.pdf. Accessed on: February 07, 2020.

[28] A. Forsey, S. Gungor, "Demosaicing images from colour cameras for digital image correlation", Optics and Lasers in Engineering, vol. 86, pp. 20-28, 2016.

[29] M. Sjödahl, "Gradient Correlation Functions in Digital Image Correlation", Applied Sciences, vol. 9, Issue 10, 21-27, 2019.

[30] Z. Tomicevic, S. Roux, F. Hild, "Mechanics-Aided Digital Image Correlation", The Journal of Strain Analysis for Engineering Design SAGE Publications (UK and US), Issue 48, pp. 330-343, 2013.

[31] Ankit Saxena, Gaurav Patil, Development of Digital Image Correlation Technique for Tensile and Compressive Tests. Thesis of work for the partial fulfillment of the course requirements of Lab Oriented Project (ME F366)-BITS Pilani, K. K. Birla Goa Campus, 2018.

[32] N. McCormick, J. Lord, "Digital Image Correlation", Materials Today, vol. 13, Issue 12, pp. 52-54, 2010.

\title{
МЕТОД ЦИФРОВОЇ КОРЕЛЯЦЇ̈ ЗОБРАЖЕНЬ ДЛЯ АНАЛІЗУ ЗАЛІЗОБЕТОННИХ КОНСТРУКЦІЙ
}

\author{
${ }^{1}$ Бліхарський Я.3., к.Т.н., доцент, \\ Yaroslav.Z.Blikharskyy@lpnu.ua, ORCID: 0000-0002-3374-9195 \\ ${ }^{1}$ Копійка Н.С., студентка, \\ kopijka.nadija.1999@gmail.com, ORCID: 0000-0003-2270-4028 \\ ${ }^{1}$ Національний університет «Львівська політехніка» \\ вул. С. Бандери 12, м. Львів, 79013, Україна
}

\begin{abstract}
Анотація. Залізобетонні конструкції широко використовуються в наші дні в різних практичних галузях, причиною чого $є$ ряд позитивних властивостей, включно з наступними: висока міцність, стійкість властивостей захищеної арматурної сталі під час експлуатації, висока стійкість до атмосферних, високотемпературних, сейсмічних та динамічних навантажень, порівняно низькі витрати на обслуговування, експлуатацію та догляд, а також низький рівень капітальних витрат через використання місцевих ресурсів. Оптимальна і ефективна методика оцінки механічних характеристик залізобетонних конструкцій $є$ важливим теоретичним та практичним питанням. Останнім часом наявна поширена практика використання методу цифрової кореляції зображень (ЦКЗ) для аналізу залізобетонних конструкцій. Основна мета даної роботи - провести ретельне теоретичне дослідження методу ЦКЗ, виявити його переваги та недоліки. У статті подано детальний огляд існуючих теоретичних наукових досліджень та експериментальних робіт, на основі яких встановлено основні позитивні параметри даного методу та аспекти його використання. Досліджено основні передумови застосування методу ЦКЗ та окреслено перспективи його подальшого розвитку. Детальний літературний огляд експериментальних робіт, в яких використовувався метод ЦКЗ засвідчив перспективність його використання для дослідження тріщиностійкості залізобетонних елементів, їх наруженодеформованого стану, фізико-механічних характеристик матеріалів, а також,-
\end{abstract}

Bulletin of Odessa State Academy of Civil Engineering and Architecture, 2020, no. 78, page 27-33 
багатопараметричного моделювання поведінки залізобетонних елементів під навантаженням. На основі проведого аналізу зроблено висновок, що метод кореляції цифрових зображень настійно рекомендовано до подальшого використання та удосконаленя 3 огляду на високу точність та простоту проведення експериментальних досліджень. Крім того, метод цифрової кореляції $\epsilon$ найдільш доцільним підходом для синхронізації експериментального та теоретичного моделювання деформівних процесів в залізобетонних конструкціях. Доцільними напрямками подальших досліджень $є$ подальше удосконалення методики для підвищення точності результатів та зменшення можливих зовнішніх впливів на отримані дані.

Ключові слова: цифрова кореляція зображень, залізобетонні конструкції, моделювання, точність, властивості матеріалів, експериментальні дослідження.

\title{
МЕТОД ЦИФРОВОЙ КОРРЕЛЯЦИИ ИЗОБРАЖЕНИЙ ДЛЯ АНАЛИЗА ЖЕЛЕЗОБЕТОННЫХ КОНСТРУКЦИЙ
}

\author{
${ }^{1}$ Блихарский Я.3., к.т.н., доцент, \\ Yaroslav.Z.Blikharskyy@lpnu.ua, ORCID: 0000-0002-3374-9195 \\ ${ }^{1}$ Копийка Н.С., студентка, \\ kopijka.nadija.1999@gmail.com. ORCID: 0000-0003-2270-4028 \\ ${ }^{1}$ Национальный университет «Львовская политехника» \\ ул. С. Бандеры 12, г. Львов, 79013, Украина
}

\begin{abstract}
Аннотация. Железобетонные конструкции широко используются в наши дни в различных практических областях, причиной чего является ряд положительных свойств, включая следующие: высокая прочность, устойчивость свойств защищенной арматурной стали при эксплуатации, высокая устойкость к атмосферным, высокотемпературным, сейсмическим и динамическим нагрузкам, сравнительно низкие расходы на обслуживание, эксплуатацию и уход, а также низкий уровень капитальных затрат в связи с использыванием местных ресурсов. Оптимальная и эффективная методика оценки механических характеристик железобетонных конструкций является важным теоретическим и практическим вопросам. В последнее время распространенена практика использования метода цифровой корреляции изображений (ЦКИ) для анализа железобетонных конструкций. Основная цель данной работы - провести тщательное теоретическое исследование метода ЦКИ, выявить его преимущества и недостатки. В статье представлены подробный обзор существующих теоретических научных исследований и экспериментальных работ, на основе которых установлены основные положительные параметры данного метода и аспекты его использования. Исследованы основные предпосылки применения метода ЦКИ и намечены перспективы его дальнейшего развития. Детальный литературный обзор экспериментальных работ, в которых использовался метод ЦКИ показал перспективность его использования для исследования трещиностойкости железобетонных элементов, их напряженно-деформированного состояния, физико-механических характеристик материалов, а также, - многопараметрического моделирования поведения железобетонных элементов под нагрузкой. На основе проведенного анализа сделан вывод, что метод корреляции цифровых изображений настоятельно рекомендуется к дальнейшему использованию и усовершенствованию, учитывая высокую точность и простоту проведения экспериментальных исследований. Кроме того, метод цифровой корреляции является наиболее целесообразным подходом для синхронизации экспериментального и теоретического моделирования деформационных процессов в железобетонных конструкциях. Целесообразными направлениями последующих исследований является дальнейшее совершенствование методики для повышения точности результатов и уменьшения возможных внешних воздействий на полученные данные.

Ключевые слова: цифровая корреляция изображений, железобетонные конструкции, моделирование, точность, свойства материалов, экспериментальные исследования.
\end{abstract}

Стаття надійшла до редакції 5.02.2020

Bulletin of Odessa State Academy of Civil Engineering and Architecture, 2020, no. 78, page 27-33 